\title{
Player Immersion in the Computer Game Narrative
}

\author{
Hua Qin ${ }^{1}$, Pei-Luen Patrick Rau ${ }^{1}$, and Gavriel Salvendy ${ }^{2}$ \\ ${ }^{1}$ Department of Industrial Engineering, Tsinghua University, Beijing 100084, China \\ ${ }^{2}$ School of Industrial Engineering, Purdue University, West Lafayette, IN 47907, U.S.A \\ qinh03@mails. tsinghua . edu.cn
}

\begin{abstract}
The main characteristics of the computer game narrative are interactive and nonlinear, so this study proposes a questionnaire aim at studying player immersion in the computer game narrative. To evaluate the questionnaire, a survey was conducted on the Internet. After factor analysis and reliability test, an instrument for measuring player immersion were obtained. This instrument not only can be applied to the computer game narrative, it also ca be used to measure user experience in story-oriented virtual reality.
\end{abstract}

\section{Introduction}

Involvement in media such as novels, movies, computer games and virtual reality has been described as an experience of feeling deeply engaged with the medium. In the research of those fields, many terms have been developed to try to account for these experiences, such as flow, cognitive absorption (CA), presence and immersion $[1,2,3,4,5]$. These terms - flow, cognitive absorption, presence and immersion have some overlap in studies, but in game research, immersion is a widely used term. In game worlds, players can see, hear and manipulate the environment, just as they do in the real world. This provides the player with a strong visceral and cognitive belief in what is experienced in the virtual context as physical reality. Ermi and Mäyrä [6] believed that immersion more clearly connotes the mental processes involved in the game. In addition, in the computer game industry, the term immersion is widely used $[6,7,8]$. Thus, the term immersion describing players totally submerged in their fictional surroundings is appropriate. Researchers consider immersion, like flow, to also be a multi-dimensional concept $[2,6,7]$. They attempt to interpret the depth or representation of the immersion in the field of the game. Table 1 summarizes the dimensions of engagement experience including flow, cognitive absorption, presence and immersion.

For the computer game narrative, one of the characteristics that make it different from traditional narratives is interactivity. Interaction is a form of participating actively in the narrative. Therefore, gamers are not only the audience, but also players and narrators. They have intense subjective experience in listening, watching and acting. Another characteristic of the computer game narrative is its nonlinear structure. The relationship between independent events is causality, not a fixed sequence. These characteristics determine that players will have different experiences

Commonly, general dimensions of engaging experience mainly include challenge, skill, time distortion, concentration, control and so on $[3,7,9,10,13,15]$. As for games, 
Table 1. Dimensions of engaging experience

\begin{tabular}{|c|c|c|c|}
\hline Author & $\begin{array}{l}\text { Engaging } \\
\text { Experience }\end{array}$ & Application & Dimensions \\
\hline $\begin{array}{c}\text { Csikszentmihalyi } \\
\text { [9] }\end{array}$ & Flow & $\begin{array}{l}\text { Human } \\
\text { psychology }\end{array}$ & $\begin{array}{l}\text { 1. Focused concentration; } 2 \text {. Merging of } \\
\text { activity and awareness; } 3 \text {. Perceived } \\
\text { control; } 4 \text {. Time distortion; } 5 \text { Loss of } \\
\text { self-consciousness }\end{array}$ \\
\hline $\begin{array}{c}\text { Hoffman \& Novak } \\
{[10]}\end{array}$ & Flow & $\begin{array}{l}\text { A computer- } \\
\text { mediated } \\
\text { environments }\end{array}$ & $\begin{array}{l}\text { 1. Consumer learning; } 2 \text {. Perceived } \\
\text { behavioral control (or confidence); } 4 . \\
\text { Exploratory behavior; } 5 \text {. Positive } \\
\text { subjective experiences; } 6 \text {. Distortion in } \\
\text { time perception }\end{array}$ \\
\hline Chou \& Ting [11] & Flow & $\begin{array}{l}\text { Online computer } \\
\text { game }\end{array}$ & $\begin{array}{l}\text { 1. Concentration; } 2 . \text { Playfulness; } 3 \text {. } \\
\text { Distortion in time perception; } 4 \text {. } \\
\text { Telepresence; } 5 \text {. Exploratory behavior }\end{array}$ \\
\hline $\begin{array}{c}\text { Skadberg \& } \\
\text { Kimmel [12] }\end{array}$ & Flow & $\begin{array}{l}\text { Browsing a } \\
\text { website }\end{array}$ & $\begin{array}{l}\text { 1. Enjoyment; } 2 . \text { Lost track of time; } 3 . \\
\text { Telepresence }\end{array}$ \\
\hline Pace [13] & Flow & $\begin{array}{l}\text { Web information } \\
\text { seeking activities }\end{array}$ & $\begin{array}{l}\text { 1. Duration; } 2 \text {. Frequency and intensity; } \\
3 \text {. Joy of discovery; } 4 \text {. Reduced } \\
\text { awareness of irrelevant factors; } 5 \text {. } \\
\text { Distorted sense of time; } 6 \text {. Merging of } \\
\text { action and awareness; } 7 \text {. Sense of } \\
\text { control; } 8 \text {. Mental alertness; } 9 \text {. } \\
\text { Telepresence }\end{array}$ \\
\hline $\begin{array}{l}\text { Sweetser and } \\
\text { Wyeth [14] }\end{array}$ & Flow & $\begin{array}{l}\text { Game player } \\
\text { experience }\end{array}$ & $\begin{array}{l}\text { 1. Concentration; 2. Challenge; 3. Skills; } \\
\text { 4. Control; 5. Clear goals; 6. Feedback; } 7 . \\
\text { Immersion; } 8 \text {. Social interaction }\end{array}$ \\
\hline $\begin{array}{l}\text { Agarwal, } \\
\text { Sambamarthy, and } \\
\text { Stair [15] }\end{array}$ & $\begin{array}{l}\text { Cognitive } \\
\text { absorption }\end{array}$ & $\begin{array}{l}\text { Information } \\
\text { technology }\end{array}$ & $\begin{array}{l}\text { Control; 2. Attention focus; } 3 . \\
\text { Curiosity; } 4 . \text { Intrinsic interest; } 5 . \\
\text { Computer; } 6 \text {. Playfulness; } 7 \text {. Ease of use }\end{array}$ \\
\hline $\begin{array}{l}\text { Agarwal and } \\
\text { Karahanna [5] }\end{array}$ & $\begin{array}{l}\text { Cognitive } \\
\text { absorption }\end{array}$ & $\begin{array}{l}\text { Information } \\
\text { technology }\end{array}$ & $\begin{array}{l}\text { 1. Temporal dissociation; } 2 \text {. Focused } \\
\text { immersion; 3. Heightened enjoyment; } 4 . \\
\text { Control; 5. Curiosity }\end{array}$ \\
\hline $\begin{array}{c}\text { Witmer and Singer } \\
{[3]}\end{array}$ & $\begin{array}{l}\text { Presence } \\
\text { and } \\
\text { immersion }\end{array}$ & $\begin{array}{c}\text { Virtual } \\
\text { environment }\end{array}$ & $\begin{array}{l}\text { 1. Presence: *Control; *Sensory; } \\
\text { *Distraction; *Realism } \\
\text { 2. Immersion: *Tendency to become } \\
\text { involved in activities; *Tendency to } \\
\text { maintain focus on current activities; } \\
\text { *Tendency to play video games }\end{array}$ \\
\hline Brooks [7] & Immersion & $\begin{array}{c}\text { Narrative in } \\
\text { virtual reality and } \\
\text { other interfaces }\end{array}$ & 1. Time; 2. Context; 3. Participation \\
\hline $\begin{array}{c}\text { Brown and Cairns } \\
\text { [2] }\end{array}$ & Immersion & Game & $\begin{array}{l}\text { 1. Emotional involvement; } 2 \text {. } \\
\text { Transportation to different place; } 3 \text {. } \\
\text { Attention; } 4 \text {. Control and autonomy }\end{array}$ \\
\hline Ermi and Mäyrä [6] & Immersion & $\begin{array}{l}\text { Gameplay } \\
\text { experience }\end{array}$ & $\begin{array}{l}\text { 1. Sensory immersion; } 2 \text {. Challenge- } \\
\text { based immersion; } 3 \text {. Imaginary } \\
\text { immersion }\end{array}$ \\
\hline
\end{tabular}


some studies have also focused on these factors including concentration, playfulness, and control $[6,11,14]$. Because this study attempts to evaluate player immersion in the computer game narrative, the researchers consider that comprehending the structure and content of the story is a precondition of immersion. Only by understanding the content and structure of a series of events the players can make a plan or reason out a strategy for the next steps. Failure to comprehend the story may lead to failure to play [16]. Another aspect for studying player immersion in the computer game narrative is emotion. Therefore, a questionnaire for this study added items of story comprehension and emotion besides general dimensions of engaging experience. The questionnaire was composed of 30 items. In order to examine the reliability and validity of the questionnaire, a survey was conducted on a website.

\section{Measuring Player Immersion}

The whole procedure of the survey see figure 1. A questionnaire constructed of 30 questions or items was conducted on a website. There were 340 participants and 309 of respondents were effective. About $70 \%$ of the respondents were students. The ages of $93.85 \%$ of the subjects were from 20 to 30 , and $95.47 \%$ had higher than undergraduate education levels. Only $36 \%$ of the participants had played games no more than 5 years. The participants supplied their personal information and brief information about their experience with computer games. Then the participants were asked to imagine a familiar game with a story frame to some degree while answering the 30 questions. The following steps were factor analysis including Exploratory Factor Analysis (EFA) and Confirmatory Factor Analysis (CFA) to find and confirm the structural characteristics of the questionnaire. The aim is to obtain an optimal and simple model. The 309 data were divided into two parts for the two factor analyses. Then reliability and validity of the instrument were tested. The results showed that original questionnaire was constructed of six dimensions and the 30 items were changed into 18 items. The reliability test was also satisfactory.

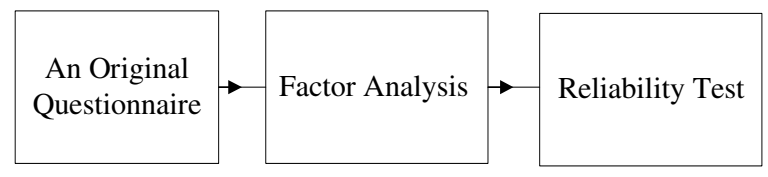

Fig. 1. The procedure of the survey

\section{Discussion}

The genres of computer games are diversiform and narratives differ in thousands of ways, so it is difficult to find a general measurement from the design aspects. However, most of computer games at present are story-oriented. This study considered that the degree of player immersion in the story could reflect the computer game narrative. Therefore, a questionnaire based on players' perception, cognition, motion and emotion at the beginning of, in the course of and after playing the games were proposed to measure player immersion. 
At present, most studies only consider the computer game narrative as one aspect of computer games. There are nearly no systematical systems for measuring the game narrative. This study explores this field through empirical methods. The instrument proposed in this study provides a starting point for future theoretical research.

\section{References}

1. Csikszentmihalyi, M.: Flow: The Psychology of Optimal Experience. Harper and Row, New York (1990)

2. Brown, E., Cairns, P.: A grounded investigation of game immersion. In: CHI 2004, ACM Conference on Human Factors in Computing, pp. 1297-1300. ACM Press, New York (2004)

3. Witmer, B.G., Singer, M.J.: Measuring presence in virtual environments: A presence questionnaire. Presence, Teleoperators and Virtual Environments 7(3), 225-240 (1998)

4. McMahan, A.: Immersion, engagement, and presence: A method for analyzing 3-D video games. In: Wolf, M.J.P., Perron, B. (eds.) The Video Game Theory Reader, New York, pp. 67-86 (2003)

5. Agarwal, R., Karahanna, E.: Time flies when you're having fun: cognitive absorption and beliefs about information technology usage. MIS Quarterly 24(4), 665-694 (2000)

6. Ermi, L., Mäyrä, F.: Fundamental components of the gameplay experience: analyzing immersion. In: Castell, S., Jenson, J. (eds.) Changing Views: Worlds in Play. Selected Papers of the 2005 Digital Games Research Association's Second International Conference, pp. 15-27 (2005)

7. Brooks, K.: There is nothing virtual about immersion: Narrative immersion for VR and other interfaces (2003), Retrieved (May 25, 2007) from http://alumni.media.mit.edu/ brooks/storybiz/immersiveNotVirtual.pdf

8. Cairns, P., Cox, A., Berthouze, N., Dhoparee, S., Jennett, C.: Quantifying the experience of immersion in games. In: Cognitive Science of Games and Gameplay workshop at Cognitive Science 2006, Vancouver (2006)

9. Csikszentmihalyi, M.: The flow experience and its significance for human psychology. In: Csikszentmihalyi, M., Csikszentmihalyi, I.S. (eds.) Optimal Experience: Psychological Studies of Flow in Consciousness. Cambridge University Press, Cambridge, MA (1988)

10. Hoffman, D.L., Novak, T.P.: Marketing in hypermedia computer-mediated environments: conceptual foundations. Journal of Marketing 60(7), 50-68 (1996)

11. Chou, T.J., Ting, C.C.: The role of flow experience in Cyber-Game Addiction. Cyber Psychology and Behavior 6(6), 663-675 (2003)

12. Skadberg, Y.X., Kimmel, J.R.: Visitors' flow experience while browsing a website: Its measurement, contributing factors and consequences. Computers in Human Behavior 20(3), 403-422 (2004)

13. Pace, S.: A grounded theory of the flow experiences of Web users. Int. J. HumanComputer Studies 60(3), 327-363 (2004)

14. Sweetser, P., Wyeth, P.: GameFlow: A model for evaluating player enjoyment in games. ACM Computers in Entertainment 3(3), 1-24 (2005)

15. Agarwal, R., Sambamurthy, V., Stair, R.: Cognitive absorption and the adoption of new information technologies. Presented at the Academy of Management Annual Meeting, Boston (1997)

16. Tavinor, G.: Video games, fiction, and emotion. In: Proceedings of the Second Australasian Conference on Interactive Entertainment, Sydney, Australia (2005) 